\title{
Images of Leisure and Outdoor Activities in the 1930s: A Mixed Archive Sources Methodology
}

\author{
By \\ Marianne Larsson
}

\begin{abstract}
In Sweden, leisure time and outdoor activities were important parts of the 1930s welfare society. The aim of this study is to examine the usefulness of some different source categories in the Nordic Museum's collections and to complement representations of 1930s ideals about health, leisure time and outdoor activities. The article is written within the scope of the Nordic Museum and Stockholm University research project Images and Stories of Everyday Life. With digitising as an overall purpose, the project focuses on two categories of source material in the museum collections-the responses to the museum's questionnaires and the photograph archive of the Swedish photographer Gunnar Lundh. Methodologically, around 400 questionnaire responses and 2,000 contact sheets have been looked at, with the aim of finding relevant representations of people's leisure time and outdoor life in the 1930s. A selected number of questionnaires are analysed, and regarding the photographs, four series are analysed and represented by a selected number of photos. Series of photos on Gunnar Lundh's contact sheets are essential, as they add knowledge beyond the individual photo. The combination of sources used in the article supports that holidays and outdoor life were part of urban people's lives, while for rural people it was not easily combined with living conditions in agriculture. These results are reflected in the museum's source material as well as in official government reports, earlier studies and historical sources. Although there is quite a large difference between the source categories, this study shows that the museum material, including evaluation of sources, makes it possible to broaden the image of Swedish people's outdoor activities in the 1930s. The bricolage research method indicates that combinations of sources enlarge the image of different groups' relationships to outdoor life.
\end{abstract}

Keywords: Leisure time, Holidays, Outdoor activities, Photographs, Questionnaires.

Larsson, Marianne: "Images of Leisure and Outdoor Activities in the 1930s: A Mixed Archive Sources Methodology", Culture Unbound, Volume 12, issue 1, 2020: 90-115. Published by Linköping University Electronic Press: http://www.cultureunbound.ep. liu.se 


\section{Introduction}

In Sweden, leisure time and outdoor activities were important elements of the 1930s welfare society. In this article, I will investigate how leisure time, holidays and outdoor activities are represented in archive sources such as photographs and questionnaire responses. The purpose is to investigate how a combination of different source categories can deepen the understanding of 1930s ideals about health, leisure time and outdoor activities.

The article is written within the Nordic Museum and Stockholm University research project Images and Stories of Everyday Life (Vardagens bilder och berättelser, henceforth VBB). With digitising as an overall purpose, VBB focuses on two categories of source material in the Nordic Museum collections. One is responses to the museum's questionnaires, delivered since the 1920s. The other is the Swedish photographer Gunnar Lundh's (1898-1960) photograph archive. Both collections contain a huge number of documents from around the same period of the twentieth century. I have limited my research to the 1930s, when the issue of people's leisure time exploded. With keywords such as holidays, leisure time and outdoor activities, I will identify and analyse representations of everyday life in these two source categories. Focus is on the content of the source material rather than its materiality or archive context, but not exclusively.

As complementary sources, I use two official government reports from the same period: the first is the committee report on the Annual Leave Act (SOU 1937:49); the other, Fritidsutredningen (The Leisure Time Report), is about establishing open-air recreation reserves (SOU 1940:12). These reports go hand in hand with the outdoor exhibition Fritiden, called the Modern Leisure Exhibition in English, shown in Ystad in 1936. There is no lack of research on the question of leisure time and outdoor activities. See, for example, Lena Eskilsson's articles about the ideas of the Fritiden exhibition as well as the Swedish history of outdoor activities (Eskilsson 1995, 2008, see also Pihl Atmer 1998; Sandell \& Sörlin 2008). Additionally, Jonas Frykman (1992) points out that the issues of health, outdoor life and a body in motion were important for many western countries between the World Wars, but had a particularly strong position in Sweden, both in the construction of the welfare state and, in a wider class perspective, in people's minds. My contribution will be to examine what kind of representations the museum's source material can provide of the 1930s discourse on leisure time and outdoor activities.

\section{Included or excluded in the benefits of the welfare state}

In 1930, when a permanent working hour law was established, it meant eight hours of work, eight hours of rest and eight hours of leisure time. In a historical 
perspective, leisure time was a new phenomenon. In 1932, the Social Democratic Party came to power, launching the ideas of a Swedish welfare state. The party's ideological ambitions were that Sweden would be a modern democratic society and a good "home" for every citizen. As a major social change, the first Swedish Annual Leave Act was established in 1938, created especially with regard to working class families. The innovative public act meant that almost all employees would receive twelve days of paid leave per year. In fact, the Swedish word for holidays (semester) actually came to mean paid leave, according to the previous official government report (SOU 1937:49: 105).

The newly established eight-hour day and the regular Sunday rest were important, but it was not enough, the official report stated. Free time and full rest for a longer period was considered necessary for the health of the workers, both in bodily and spiritual terms. An important part was also to prevent accidents during work. The issue of health was not the only idea; another aim was for workers to have time to devote themselves to interests that they would not otherwise have time to engage in. One example was opportunities to engage in outdoor activities or to acquire new impressions through travelling (SOU 1937:49: 104-116). The Annual Leave Act came into force on July 1 1938. For the first time, working class families had the legal right to spend two free weeks together. In many ways, this was a cultural change that affected people's lives.

However, as a part of the welfare project's ambitions to educate good citizens, the issue of leisure time was problematized. An important question concerned how working class families should spend their holidays in the best possible way. Holidays should not be wasted on frivolous activities such as dancing and immoral movies or laziness and idleness; they should be devoted to education, culture, fresh air and vitalising outdoor activities. The employees' leisure time became a challenge for the modern Swedish society. On the other hand, far from everyone was affected by the Annual Leave Act. The official government report states that the Annual Leave Act and paid holidays would not include independent entrepreneurs (SOU 1937: 49: 116). People running their own businesses were excluded, for example the large number of farmers. Another excluded group was the around one million unpaid housewives (Eskilsson 1995: 26).

As Swedish natural resources, namely iron and wood, have for centuries generated large export revenues, nature was an important component of the national identity. Nature tourism and outdoor activities were consequently important elements of society's attempt to increase the productivity of the working class, as well as their quality of life (Sandell \& Sörlin 2008: 64-65). The aim was to raise strong and healthy citizens. An essential part of the ideology was to encourage and take responsibility for people's leisure time, with health, body and outdoor recreation as important elements. This phenomenon was not unique 
to Sweden; in Norway, the eight-hour day was introduced in 1919, and an Annual Leave Act was established in 1937. With the same rhetoric as in Sweden, the issue of how to teach people to use their leisure time in the right way was one of the big social questions of the time (Lyngø 1993: 22-24).

\section{Analysing Series of Photos: Showing a few Pictures}

As an elementary way to identify photos of outdoor activities, I browsed around 2,000 contact sheets in chronological order to perceive the flow. As there are around 30-36 photos on each contact sheet, I looked at around 70,000 contact prints. "Reading" the contact prints was a pleasure, although it took a lot of time. It was not hard to find photos of people swimming, cycling, sailing, camping and enjoying leisure time and fresh air. Among thousands of photos, with a huge number showing outdoor activities, I decided to work with four photo series which express my theme and keywords. My intention is to analyse and draw conclusions from a series of photos, although only a few examples are published in the article.

An important manifestation of the authorities' efforts to educate the citizens in positive holiday habits was the outdoor exhibition Fritiden in 1936 in Ystad, Skåne. As Gunnar Lundh was born in Skåne, and obviously fond of photographing outdoor activities, I was not surprised to find that he documented the Fritiden exhibition. Consequently, Lundh's series of photos of this occasion will work as a constructive starting point for the analysis. According to his series of photos and the frugal notes on the contact sheets, he visited the exhibition over two or three days in the middle of July. There are only a few people moving around in the exhibition area; it looks like it was a bit windy and chilly, as some are wearing coats and hats. The photo series, including around one hundred photos, show the exhibition pavilions, parks, plants, ponds, ornaments and areas for outdoor activities. Additionally, a lot of photos show information panels with text and photomontages. Lundh's photos of the panels look instructive, but sometimes a little tilted and blurred, without obvious aesthetic ambitions. As I, to start with, only had access to the contact sheets, I could not read the texts. To get a closer look at the message of the exhibition, I had to order high-resolution digitised photos.

According to the VBB project's purpose of making Lundh's photos available to the general public, I ordered all the photos in the series from the exhibition. The two sceneries published below are the very first photos in the series; in this article they are meant to introduce the reader to the exhibition area. From the series, I know that the entrance is situated behind the flagpoles and the big introduction panel on the first photo. The second photo shows the arched building containing the main restaurant, which was built for the exhibition and still remains, today holding a sports hall. 


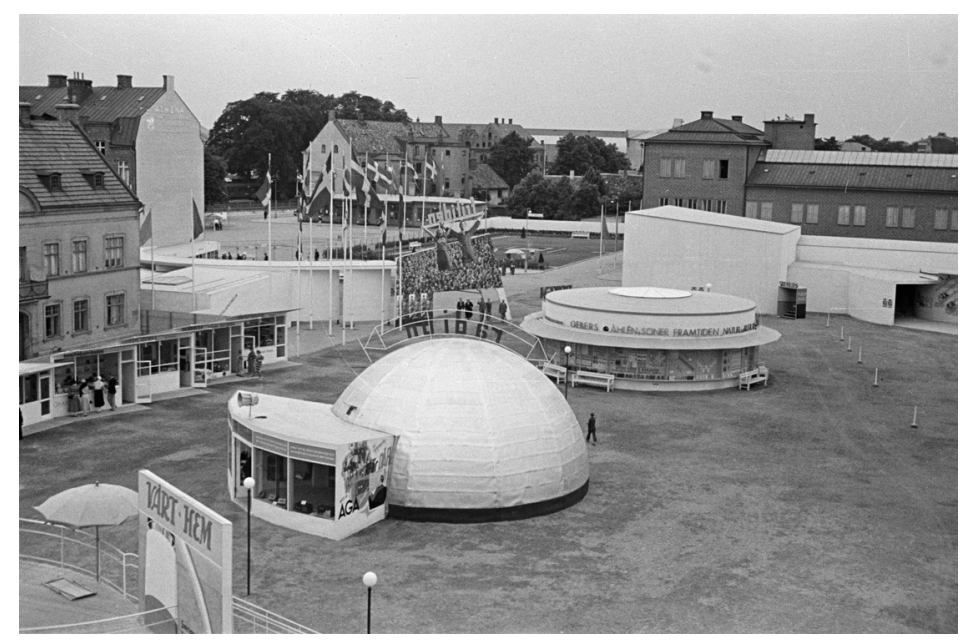

Fig. 1 View over exhibition pavilions and behind them, the introduction panel and the entrance of the Modern Leisure Exhibition (Fritiden) in Ystad, July 15/16 1936. Photo: Gunnar Lundh (NMA.0078752).

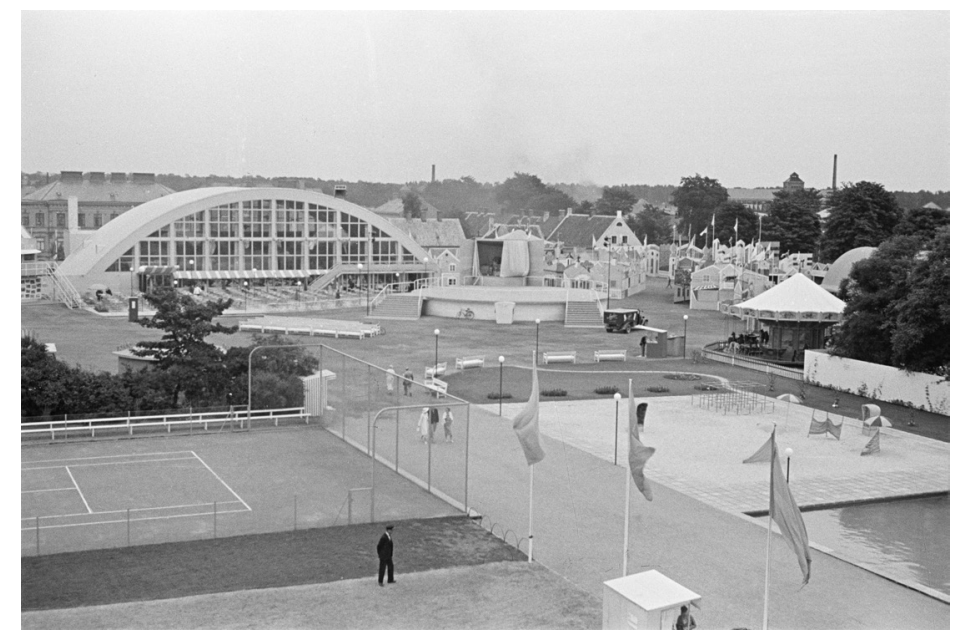

Fig. 2 View of the exhibition area, with a tennis court in front and the arched building containing the main restaurant in the background. Fritiden, July 15/16 1936. Photo: Gunnar Lundh (GL.113332).

The Fritiden exhibition was on display between June 19 and August 23 1936, and was arranged by Ystad municipality in collaboration with the Swedish Handicraft Association (Svenska slöjdföreningen). ${ }^{1}$ In the press, the exhibition was noted as an attempt to highlight a current social problem expressed in modern exhibition design. The indicated problem was that leisure time and holidays must not be wasted on bad activities, while the innovative photomontages represented the modern exhibition design (Eskilsson 1995; Svenska Dagbladets Årsbok 1936: 77). 
As the modern view of leisure time caused concerns among politicians, authorities, public educators and psychologists, Fritiden was arranged with aspirations to teach people how to use their leisure time and holidays in the best possible way. According to the catalogue, the exhibition would illustrate the idea of leisure time. As a part of communal benefit and democracy, a proper use of leisure time should make people happy and healthy, as was the current ideal for modern humans (cf. Eskilsson 1995). The English version of the exhibition catalogue expresses the idea like this:

If the people are unable to fill up their leisure hours in such a way that they derive health and pleasure from it, then it is for the community to help them by advice and action, give them the possibility of spending their leisure time in a richer, finer and more profitable manner. The leisure time in this way becomes a concern of the community with an importance as great as that of working time (Modern Leisure 1936: 20).

Details that are possible to read on the high-resolution photos show that the visitors were met at the entrance with a series of large panels with photomontages and text information. One of the headlines emphasises that the modern leisure problem was born with industrialization, and another points out that leisure time strengthens muscles and minds with sports and outdoor life. The exhibition gave detailed information on how working class people (and other visitors) should use

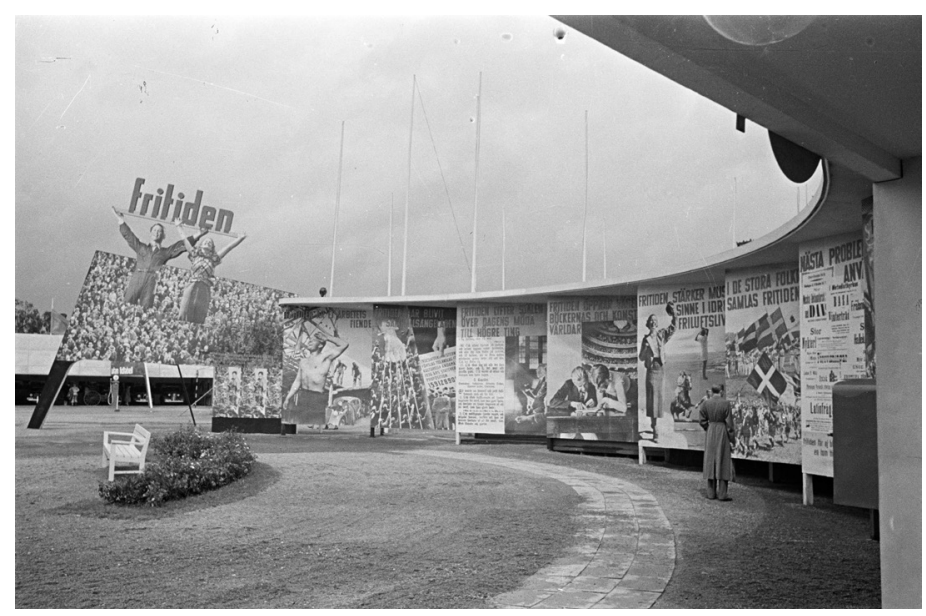

Fig. 3 The introduction panels with their innovative photomontages met the visitors inside the entrance. To the left, the main panel showing a young couple stretching their arms in the air, while standing in a crowd of (primarily) men. Fritiden, July 17 1936. Photo: Gunnar Lundh (GL.113348). 


\section{Culture Unbound}

Journal of Current Cultural Research

their leisure time; panels on different outdoor activities were combined with facts about hobbies like photography and philately, church activities, bank savings and book publishing, newspapers and journals. Other panels referred to travelling by car, bus, train, boat and airline. The tone was inspirational and educational.

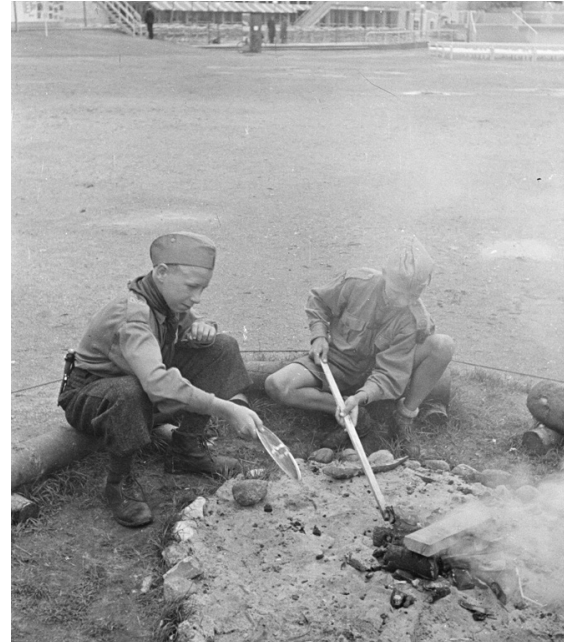

Fig. 4 Two boy scouts keep the campfire alive. As inspiration to go hiking and camping, scouting was a vital element of the exhibition. Fritiden, July 16/17 1936. Photo: Gunnar Lundh (GL.113365).

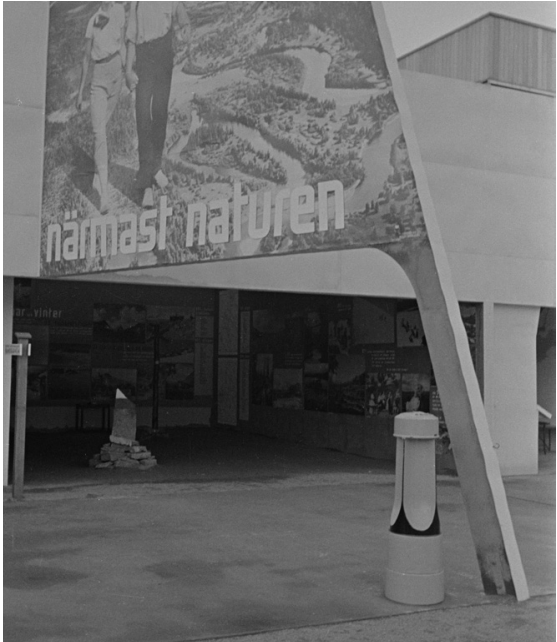

Fig. 5 The panel "Closest to Nature" shows a photomontage of a young couple hiking in nature, dressed in outdoor clothing. The photo series shows that there are further displays in the dark area behind the panel. Fritiden, July 16/17 1936. Photo: Gunnar Lundh (GL.113411).

As Lena Eskilsson expresses it, the exhibition was primarily addressed to men, as men were associated with their work while women were the heads of the home sphere. Still, young women are seen hiking in the landscapes or relaxing on the beach, illustrating the healthy outdoor life. In fact, a young woman wearing a swimsuit or sundress was used as a logo on the posters and on the cover of the catalogue. Standing in a crowd of people (mostly men) she raises her arms in the air. Even if it cannot be discerned in the photo series, associations for housewives had reacted strongly to not being invited to participate in the exhibition. As these women had no possibility of receiving paid holidays, or going on holidays at all, they had obviously not been considered. After some agitation, which was well noted in the press, they were invited to participate at the very last moment (Eskilsson 1995: 25-29, Svenska Dagbladets Årsbok 1936: 76-77). 
The exhibition attracted around 350,000 visitors during the summer and, visibly, Gunnar Lundh was one of them. The photo series shows that the Stockholm Association of Photography (Fotografiska Föreningen, Stockholm) was represented, and Lundh was probably interested in the innovative photomontages as well. Either way, as a news reporter, he contributes to the image of the 1930s leisure time discussions.

\section{Gunnar Lundh and the Documentary Impulse}

By browsing the contact sheets, I have followed Gunnar Lundh travelling around, both in Stockholm where he lived and in the countryside. Following the flow of the contact sheets is like experiencing the 1930s as a movie, directed by Lundh himself. Due to the selection of series and photos, this article also involves my interpretation of Lundh's photographic work. Since outdoor activities are a major theme in Lundh's photo archive, I limited the quantity of selectable photos to his black-and-white, small-format photos from the 1930s. During this decade, the Annual Leave Act was in progress as well as the official report about recreation reserves. During this period, Lundh participated in a variety of outdoor activities bringing his cameras with him. Despite his careful arrangements, with contact prints mounted on designed binder pages, the notes about the photos are sparse. A year is usually given, as are the locations where the photos were taken, but the names of the people depicted are seldom included.

Gunnar Lundh was born in Skåne and moved to Stockholm in 1930 (cf. Steinrud in this issue). While working in his new home town, he documented ordinary city life, and according to his choice of photo subjects-modern city buildings, parks, suburbs and other facilities-he was obviously inspired by modern society and, in fact, outdoor activities were expressions of modernity as well. It was all about the modern human being's health and life quality as an important part of democracy and the growing welfare society. Lots of photo series show that Lundh often participated in outdoor activities within organised groups. He went on walking, skiing and biking tours; he participated in boat trips and mushroom excursions. The photos express the modern outdoor activities of the time in inspirational ways even though we do not know who the depicted people are or which socioeconomic group they belong to. We do not know if people are on holidays or if they are on a weekend trip, and we do not know if Lundh participated in the excursions primarily in view of his commercial photo agency or for his own well-being. Probably it was a fruitful combination. As Lundh was running his own business, the Annual Leave Act did not include him; he had no paid holidays. 
In the summertime, Lundh often made excursions in wide circles from his childhood home in Mölle, in Skåne, by bike or, later, by car. Locals, tourists, landscapes, farmers' traditional work and the Swedish Tourist Association's (STF) youth hostels are recurring themes in the photos, and he seems to visit a number of beaches. Maybe his focus on beaches and swimming can be traced to his upbringing in the 1910s, when his father, the photographer Peter P. Lundh, earned some money by taking photos of groups of freethinking men and women swimming and enjoying themselves on the beach at Ransvik near Mölle (cf. Larsson 2011, 2014, Ranby 2013). Inspired by his father, Lundh started his education as a photographer in his younger years.

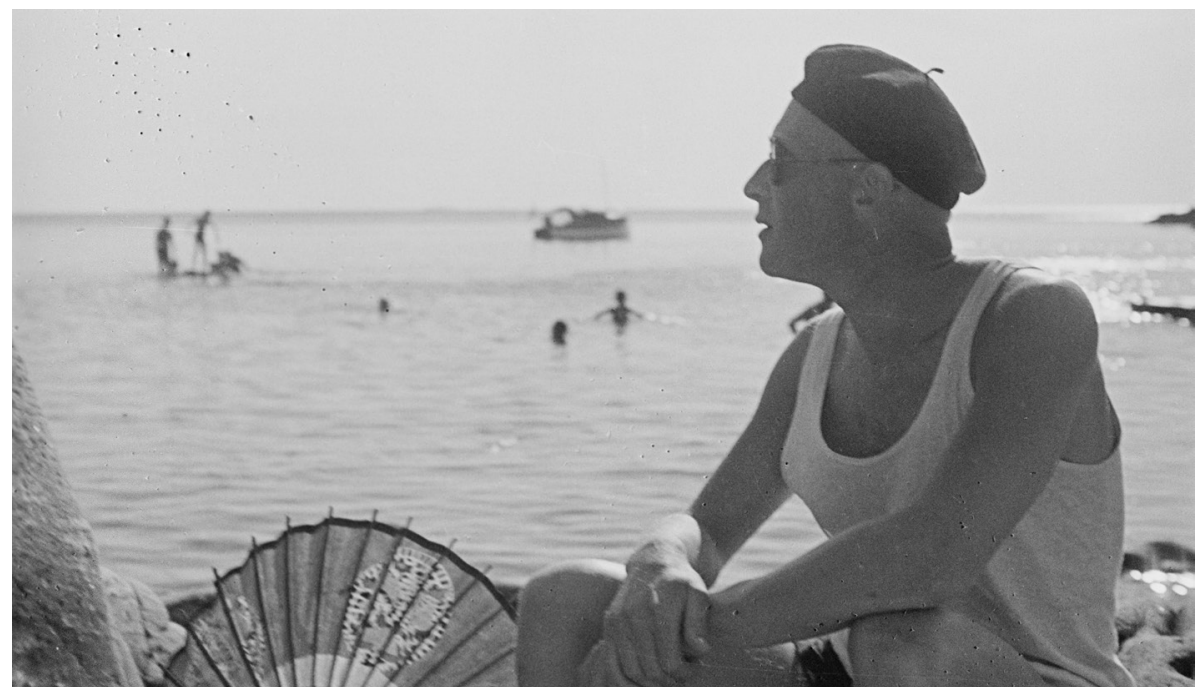

Fig. 6 Gunnar Lundh dressed in leisure wear and beret. Self-portrait on the beach in Ransvik, Skåne, 1934. Photo: Gunnar Lundh (GL.81347a).

Gunnar Lundh seems always alert to photograph subjects that appear in front of him: expressive people, beautiful landscapes, glittering seas and unexpected events. Like many photographers, Lundh visualised the surroundings through his camera, noticing occasions that might otherwise pass him by. The photographer Stuart Franklin calls an approach like this "documentary impulse". He uses this concept to describe the photographer's passion to preserve experienced moments, things they witness and might want to reform, or people, places or things they find remarkable. "The driving factors behind this impulse throughout history have included curiosity, outrage, reform, ritual, self-assertion and the expression of power," Franklin writes. "These factors encompass the search for evidence, for beauty, even for therapy-and always the search to make memorials immortal" 
(Franklin 2016: 5). According to his impressive and lively photo archive, Lundh should be seen as a documentary photographer. ${ }^{2}$ Franklin adds that documentary photography is a question of more prosaic impulses as well; for instance, making money. As one of the first photographers in Sweden to organise a commercial photograph agency, money was of course important to Lundh (Söderberg \& Rittsel 1983: 271). Most likely, his work could be both impulsive and well-planned.

It was Gunnar Lundh's innovative, small-format Leica camera that made the impulsive photography possible, even though he often carried with him his camera case containing a number of cameras. The Leica was introduced in 1925 and Lundh bought his in Germany in 1927 (Ranby 2013: 12). Designed for roll film, the camera was so small and handy that it could easily be kept in the pocket. Internationally, the Leica broke through as a press photographer camera around 1930. At the time, Lundh was the only Swedish photographer who used a small-format camera. In contrast to the still dominant bellows cameras that used glass plates, the Leica could be used relatively discreetly and the photographer could more than ever catch movement in flight, as the photo historians Rolf Söderberg and Pär Rittsel highlight (1983: 261). Lundh was early in his use of colour slides as well, not least when he documented outdoor activities. In contrast, when his father photographed bathers in the 1910s, he had to use a big bellows camera balancing on high legs on the pebble beach.

\section{Story-telling by a Series of Photographs}

On 25 September 1938, Gunnar Lundh participated in a mushroom gathering excursion to Adelsö on lake Mälaren. Among several inspiring photo series, I have chosen to analyse this one, as it visualises in a telling way outdoor activities in the 1930s. The fact that such a crowd of people walked into the forest made me curious. On the contact sheets, Lundh has noted by hand that they went to Adelsö by the SS Viking to pick mushrooms. The excursion is depicted on 119 contact prints (all ordered as high-resolution digitised photos) mounted on four contact sheets. Apart from the date, two names of depicted persons and a note about a small Adelsö ferry, there is no other information but the photos. Nevertheless, a worthwhile story about outdoor activities is visualised.

The SS Viking departs Stockholm from the quay near Stockholm City Hall, with a crowd of men and women on board. Arriving at Adelsö, the people walk into the woods with baskets in hand, climbing over fences and passing open fields. They are filling their baskets with mushrooms and they are showing each other their finds; they are talking and laughing. During a break, maybe for lunch, some are looking in a book, probably a mushroom handbook. Some of the women wear skirts, wool jackets and hats, stockings and walking shoes, while others wear short 
sports jackets, plus forts and boots. Some of the men are wearing suits, others jackets and plus fours. Some are wearing more casual clothes than others. One man, on the contact sheet named as "Hugo Stellin" (sic), looks a bit different as he is wearing a hat and a three-piece suit with a tie. The man is depicted in several photos; the situations and his authority indicate that he is the expert and perhaps the leader of the group. ${ }^{3}$

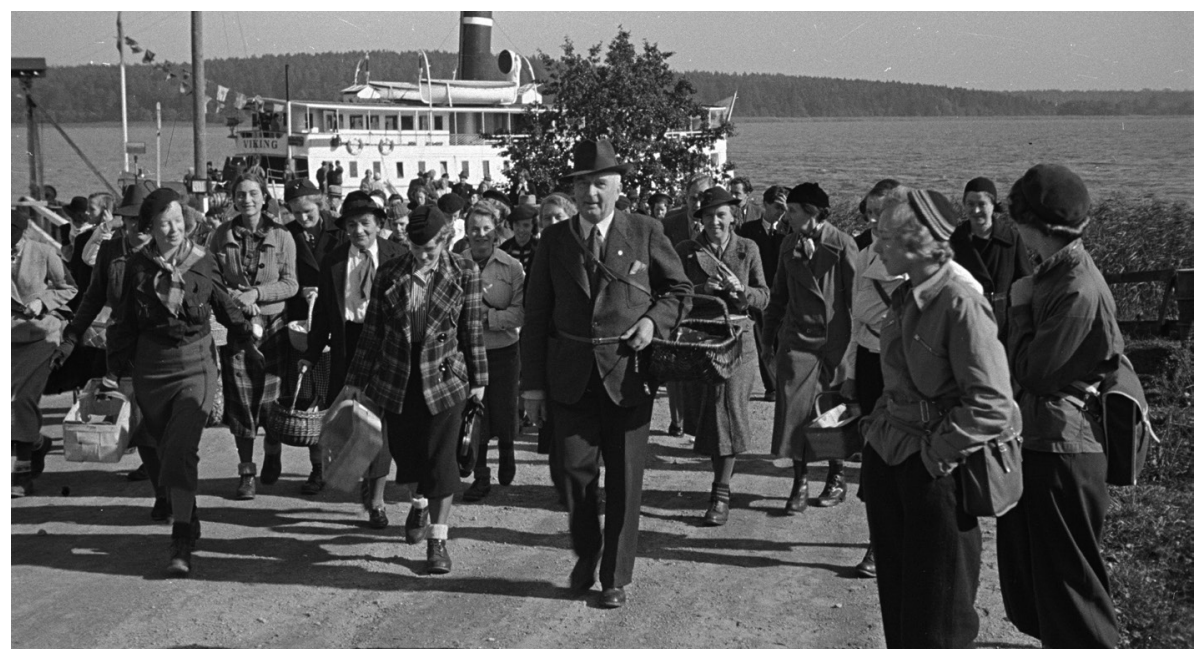

Fig. 8 The mycologist Hugo Stelin (dressed in three-piece suit) leads the crowd of mushroom pickers as they are leaving the SS Viking at Adelsö, September 251938. Photo: Gunnar Lundh (GL.131061).

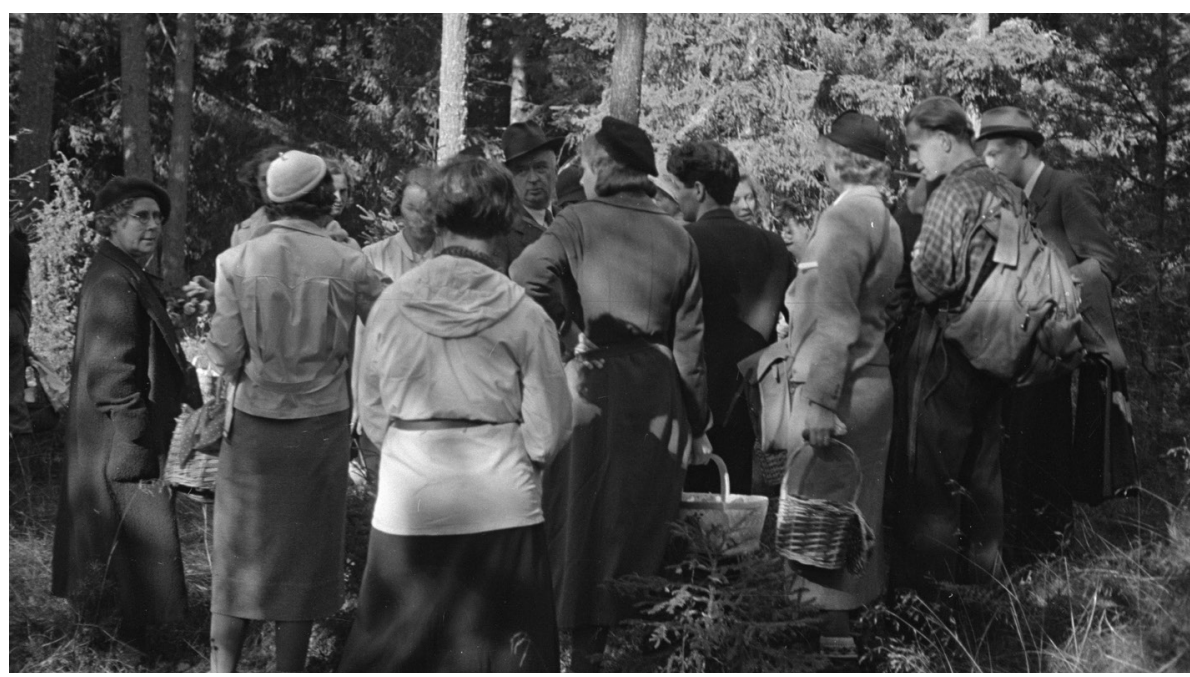

Fig. 9 A group of mushroom pickers gathered in a glade in the forest, with focus on the expert Hugo Stelin standing in the middle. Adelsö, September 25 1938. Photo: Gunnar Lundh (GL.131095). 


\section{Culture Unbound}

Journal of Current Cultural Research

A quick look on the internet indicates that Hugo Stelin was a famous mycologist and the author of several mushroom handbooks and mushroom posters (for example, see Stelin 1936 and 1950). ${ }^{4}$ An article about Stelin shows that he gave lessons, excursions and exhibitions in Stockholm with the aim of teaching people how to use mushrooms for food. Among many other activities, the excursions with the SS Viking are mentioned. Sometimes these popular excursions gathered up to 500 persons, according to the article (Strid 1999). A complete study based on Gunnar Lundh's photo series and the story of Hugo Stelin's work and mission would be an interesting contribution to the history of 1930s health missions and outdoor activities. Perhaps the healthy outdoor life was not the main purpose of this particular outing, but rather the possibility of supplementing the food account during times of crisis. In earlier times, particularly among rural people, mushrooms were not accepted as food, not even in times of famine and poverty. In the 1930s, however, by various forms of education and promotion, mushrooms began to be accepted as food in wider circles (cf. Svanberg \& Lindh 2019).

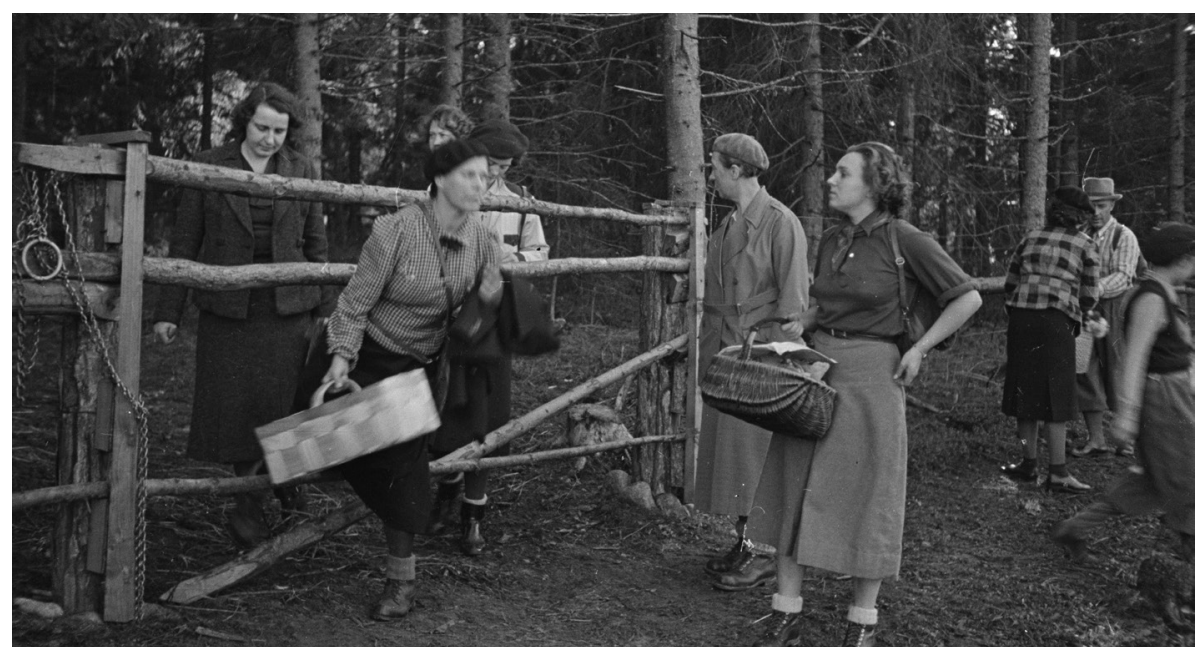

Fig. 10 Dressed in outdoor clothing and with baskets in hand, some of the mushroom pickers are climbing through a fence in the forest. Adelsö, September 251938. Photo: Gunnar Lundh (GL.131127).

The main purpose of publishing these five single photos, from a series of around hundred photos from Adelsö, is to give a visual view of the event. Second, I subjectively picked out photos of good photographic quality. As an additional asset, the identification of Hugo Stelin allowed for a deepening of the story visualised by the photo series. Together with other sources, it is possible to tell something about his role and status in the crowd and it is interesting to note that outdoor life was practised in such large groups. In addition, the cultural-historical 
context of Swedish people's outdoor activities is visualised by the photo series. In the following, I will look at whether the photo series can be further understood by relating them to the Nordic Museum questionnaire responses.
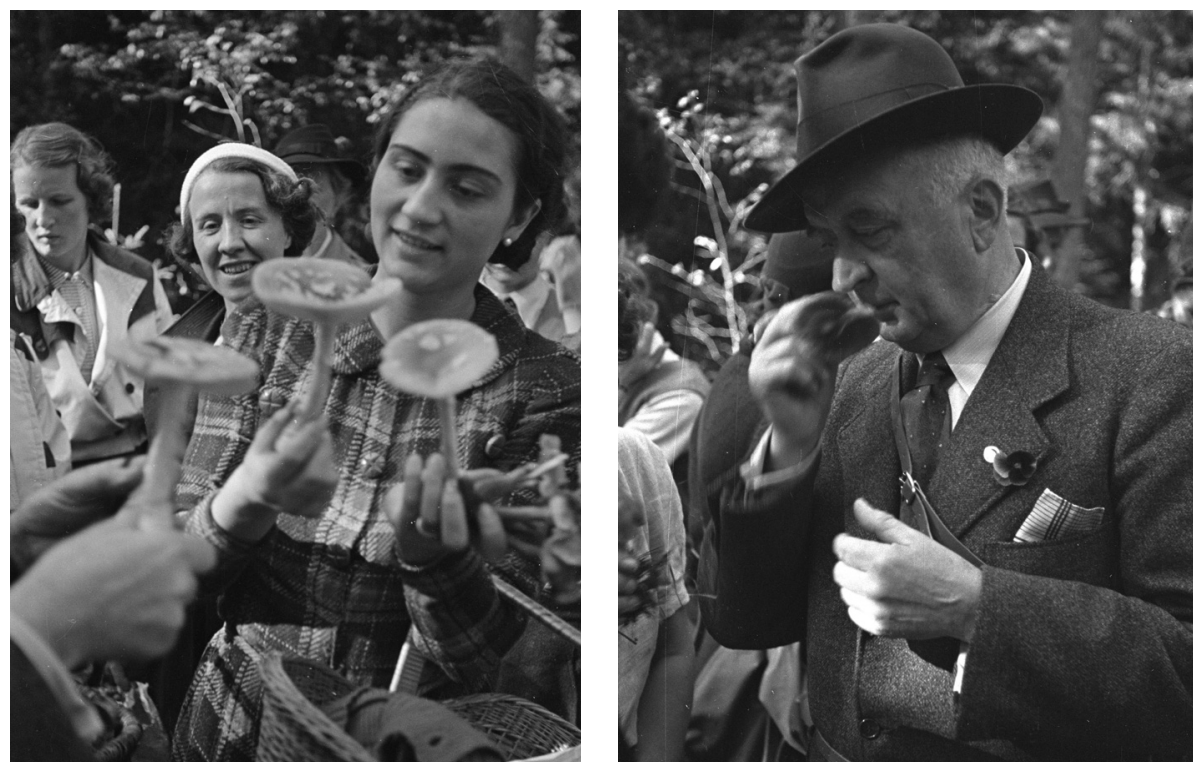

Fig. 11-12 The mycologist Hugo Stelin examines and assesses the fungi. Other photos show that the fungi on the photo to the left are fly agaric (Amanita muscaria). Adelsö, September 25 1938. Photos: Gunnar Lundh (GL.131088, GL.131092).

\section{How to Find Relevant Questionnaire Responses}

For nearly one hundred years (since 1928), the Nordic Museum has delivered recurrent questionnaires to a fixed panel of informants. The museum employees, as well as internal and external researchers, have initiated a number of different themes for the questionnaires. For years, there have been ongoing discussions and problematisation regarding the usefulness of the questionnaire responses as source material (see, for example, Nilsson, Waldetoft \& Westergren 2003). At the same time, there are several research perspectives presented; in this study, I concentrate on the informants' stories rather than on the context of the questionnaire project. Most of the responses, today collected in the museum archive, were transcribed on typewriters in the 1980s. The purpose was to make the archive more available to researchers and to protect the original documents from unnecessary use (Österman 1991). In the 1990s, the transcripts were scanned with digital OCR technology, which made full text searching and page-by-page browsing possible.

Since the questionnaire responses were already digitised, my first idea was to use a number of predetermined keywords to take advantage of the digital possibilities. My purpose was to use the Swedish words for outdoor activities, 
leisure time and holidays, swimming, hiking, biking and camping. It was a good idea, but it did not work. The Swedish word for holidays (semester) failed immediately because it gave an unreasonable number of results. In contrast, the word semesterlag for Annual Leave Act only appeared twice, and in these cases, the informants did not discuss or reflect on the new Annual Leave Act, but, rather, wanted to say something about the 1800 s by referring to the modern concept of "semesterlag" as a contrast to old fashioned living. For instance: "The annual free week was the servants' holiday long before an Annual Leave Act was ever conceived" (Nm 72, EU 24961, my translation).

My searches for keywords in the entire digitised material repeatedly produced too many results. Instead, I went to the analogue archive lists to find questionnaires with topics that seemed to be relevant to the study, such as themes like Midsummer from 1939 (Sp 70), Bathing from 1952 (Nm 159) and Bicycle from 1966 (Sp 212). But it was still difficult to find sources from the 1930s. To begin with, it was not possible to search for keywords within a particular questionnaire; it was only possible to conduct full-text searches of the entire digitised material. Another explanation was that the 1930s had become somewhat invisible when the focus of the questionnaires was changed in the 1960s. Instead of asking older natives about local traditions from times as far back as possible, the questions would now deal with the informants' own experiences. The new direction was connected to society's fast structural change and the current mobility and changeability in the traces of the agricultural society's change into an industrial society. "We want to know what it's like now", Associate Professor Anna-Maja Nylén stated (1961, 1964: 2, cf. Nilsson, Waldetoft \& Westergren 2003). This theoretical reversal led to a time gap. The questionnaires sent out before the 1960s resulted in stories of older times and traditions, while those sent out from the 1960s focus on the contemporary. According to the old structure, the responses to the questionnaires about midsummer, bathing and biking often gazed back to the nineteenth century or the early twentieth century. Even an article based on the bicycle questionnaire from as late as 1966 was exclusively about the emergence of the bicycle in the late nineteenth century (Österman 1967).

Once again, I had to try new directions. By going back to the archive lists, I found Fritiden 1973 (Nm 198) and Semestern (the holidays) from 1978 (Nm 203). The introduction to the questions of Semestern expressed that these two questionnaires were parts of a special project; at the time, the museum had leisure time as a special theme. Referring to the 1938 Annual Leave Act, the informants were asked to recount as much as possible about different holidays during their lives (Nm 203: list of questions). Despite the late date, the informants were asked to write about the past, but now with a focus on their own experiences. This was good news but, unfortunately, I realised that these responses had never been digitised, as they had never been sent for transcription. That was why there 
were no traces of them in the database. As a result, I had to turn to the original documents in the museum archive.

\section{Looking for Traces of Holidays and Outdoor Activities}

The Fritiden 1973 questionnaire generated 182 responses, while Semestern from 1978 generated 225 responses. For this investigation, I have read a selection of the around 200 responses to each questionnaire. Some informants had sent only one or two pages while others supplied lots of pages, in some cases together with photos and drawings. Indeed, it is slow work to read the original documents, written either by hand or on typewriter. On the other hand, the slow reading provides an overview that may otherwise be overlooked when using full text searching based on individual words.

I started with Fritiden 1973, focusing on the responses to the individual question that was specifically concerned with regulated holidays. It soon became apparent that many of the informants belonged to an older generation of farmers. ${ }^{5}$ A lot of them were born in the late nineteenth century and had reached retirement age. The common view was that they had no possibility at all to leave their animals for leisure time or holidays outside the farm. The farmer Harry Olsson in Västergötland (born 1910) described it like this:

For a small farm, holidays is an unknown term, we are three in the family, my wife, her sister and I (all over 60 years old). We have a small farm approx. 13 acres (tunnland) of fields, and 10 acres of woods, and we have 5 cows and around 30 chickens (Nm 198, KU 5161, my translation).

As mentioned before, the large group of farmers (running their own business) were not included by the Annual Leave Act. Still, around 40 per cent of Sweden's population were farmers, and in 1937 around 75 per cent of the farms were smallholders, a group that grew in the 1930s. At the same time, it was becoming clear that most of the traditions surrounding farming would have to stand back in relation to the emerging modern society and increasing number of industrial workers (Hirdman, Björkman \& Lundberg 2012: 54-56). Some informants talked with obvious disdain about such luxury living as leisure time. Others mentioned employers who returned home to their father's farm and women who took care of the home and elderly parents during their paid holidays. Leisure time was not used to rest or take part in outdoor activities; in many cases, the holidays were spent on unpaid home-related work. But there were, of course, many informants who made holiday trips within Sweden, the Nordic region or even in Europe. 
Several mention Norway or Austria. However, among people from different social groups, the most common activity was to spend the holidays on long bicycle rides, with outdoor camping in a tent or staying at a youth hostel. ${ }^{6}$ During the 1930s, the practice of camping and even the word camping was a part of modernity (cf. SAOB 1935: Kamping). Even though the focus on Fritiden 1973 was on the year 1973, the industrial worker Gustaf Svensson from Småland (born 1893) wrote a short flashback:

We got a statutory two weeks of holidays in 1940, just after the war broke out and the borders were closed. Then, the usual bikes came into use. You bought a season ticket at the Swedish Tourist Association and stayed at a hostel for 75 öre per night ... [...] It was easy to travel on the country roads as the cars stood still in the whole country, in the absence of rubber and gasoline (Nm 198, KU 5677, my translation).

The Annual Leave Act was one reason for the great cycling boom of the time. My browsing through Gunnar Lundh's contact sheets shows that the photographer himself cycled and while travelling around on the countryside he used his camera frequently. In July 1937, he visits STF's youth hostel Stocklycke in Omberg in Östergötland (as noted on the contact sheets). Outside the hostel, he photographs two young women - their names are not noted - while they are helping each other with their camping equipment, panniers and suitcases. The number plates S-M
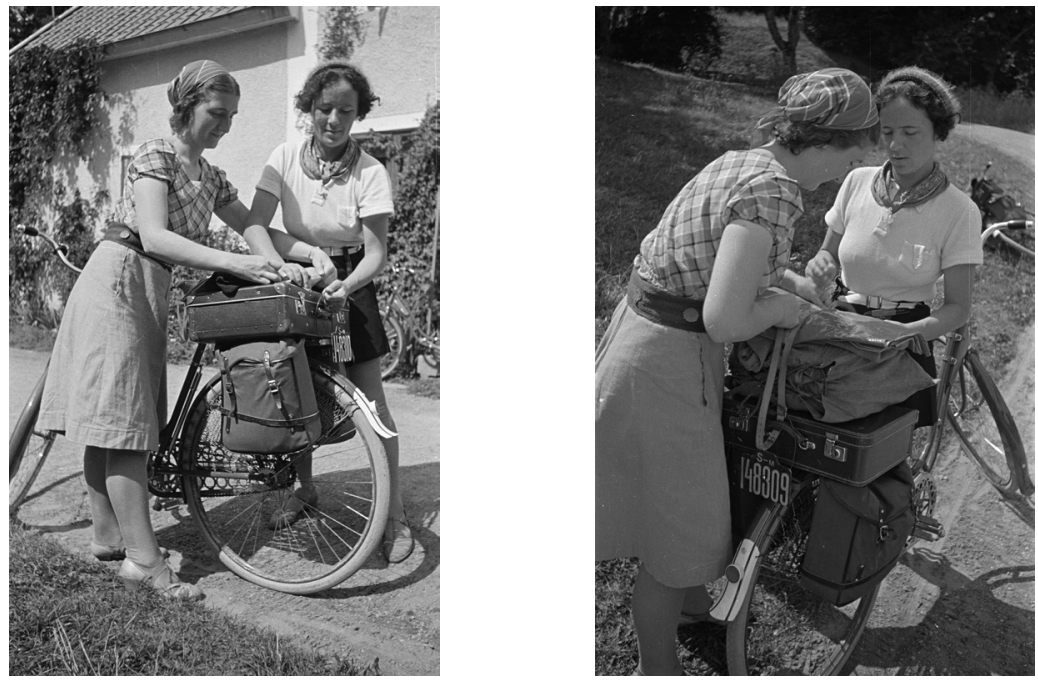

Fig. 13-14 Two young women prepare their pack, dressed in up-to-date clothing for outdoor activities. One woman is wearing a checked blouse, a divided skirt and a kerchief on her head. The other is wearing shorts, a jumper with a collar, a kerchief around her neck and a small cap on her head. Both are wearing long stockings and sandals. Stocklycke, Omberg, July 30 1937. Photos: Gunnar Lundh (GL.123271, GL.123278). 


\section{Culture Unbound}

Journal of Current Cultural Research

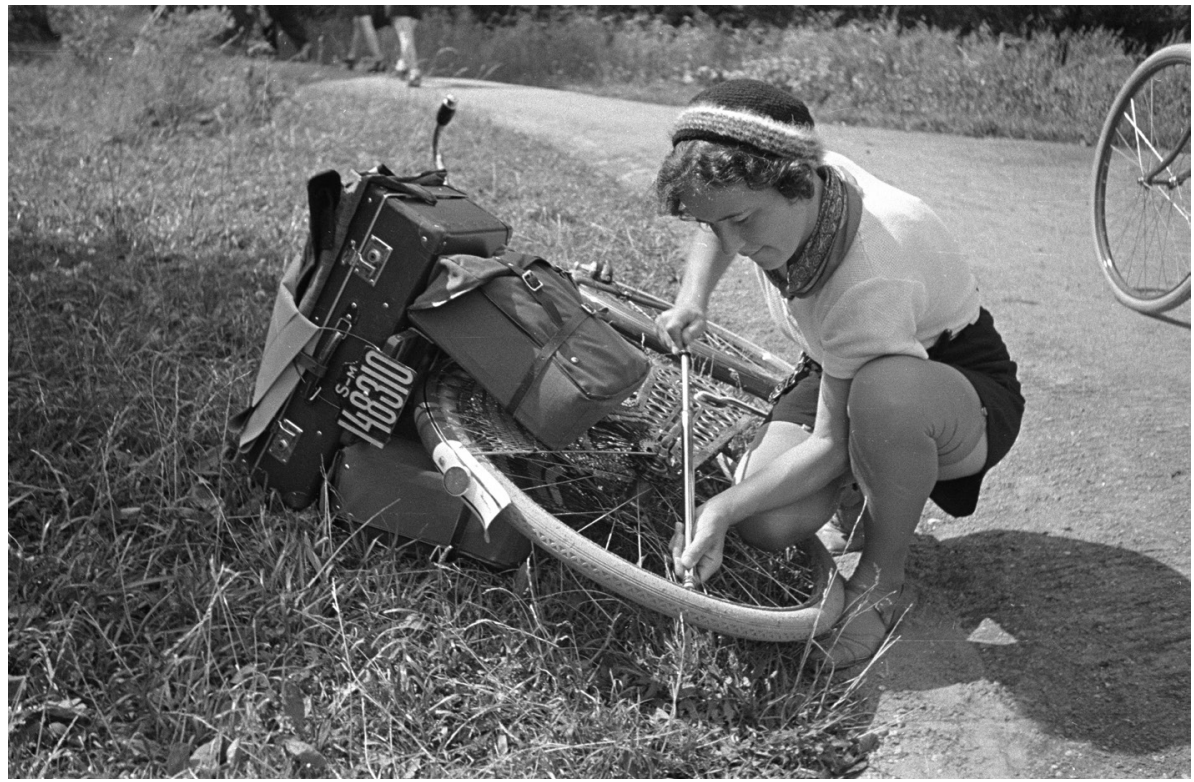

Fig. 15 Before leaving, the woman is pumping her bike. In the 1930s, "Shorts" was a new word in the Swedish language, as well as a new and modern garment. Stocklycke, Omberg, July 30 1937. Photo: Gunnar Lundh (GL.123280).

148309 and S-M 148310 show that their bicycles were registered in Stockholm between 1932 and 1939. In Sweden, the number of bicycles increased from just a few ones sold at the beginning of the 1930s, to one and a half million in use in 1937 (Ekström 2001: 72, 163).

The photo series from Stocklycke and its surroundings contains around 90 black-and-white photos, showing groups of young visitors (men and women) outside the youth hostel as well as their walking tours and boat trips in the neighbourhood. The series, with the published photos as subjectively selected examples, complements the story about 1930s outdoor activities. It supports the questionnaire responses and visualises the representations of a bicycle boom as well as the story of the recently introduced STF youth hostels. But the young people in the photos are unknown, and so is their socioeconomic status. Included in the series are a number of self-portraits of Gunnar Lundh together with some of the young people; maybe he was among friends-it is impossible to know. Anyhow, the series could be a starting point for a discussion of how the welfare state provided for cycling and camping, how STF and the youth hostels were organised and, not least, the image of women's outdoor clothing (which is in line with my own field of research). 


\section{Finding the Most Relevant Results}

In the end, the responses to the questionnaire Semestern, with several stories about different holiday experiences during the informants' lives, turned out to include the most relevant results to my study. The 225 responses, written by hand or on typewriter, are collected in nine archival storage boxes. For this article, I have browsed through four of the boxes to get an impression of the material. I soon found that ironic accounts from farmers about holidays were recurrent. There were also many informants of different ages who described holiday adventures of all kinds. Still, a common comment was that paid holidays was an unknown concept in older times. A few examples show how informants could write about holidays.

Lisa Andersson from Södermanland, married to industrial worker Gunnar Andersson, was around 77 years old when she received the questionnaire Semestern in 1978. Her response includes twelve handwritten pages. Living in a small cottage in the countryside that had belonged to her family for a long time, the moment of writing reminded her that her people had lived there in poverty and that it was a hard struggle for the families and their children. "They had rarely any free time and nobody knew what holidays were", she adds. Nowadays, she was delighted to see the summer guests arriving to the cottages around hers and wished them all the relaxation they could get. Lisa remembers that they spent Gunnar's first paid holidays-one week in the summer of 1939-with her in-laws who lived in the neighbourhood. She points out that her husband's first holiday, when she took time off herself, was the fairest and the best, probably because they never had experienced leisure time together before. She also expresses that she never had any paid holidays herself, as the Annual Leave Act did not include her work with laundry and cleaning for different employers. For Lisa and Gunnar, as for many workers, the enjoyment of paid holidays came to an abrupt end due to the outbreak of the war in September 1939:

Then it took five years before we could have a real holiday again, when the war broke out in the world, it meant that Gunnar was enlisted for long periods, and the few free days he got we spent at home with shorter bicycle trips (Nm 203, KU 7138, my translation).

In contrast to Lisa Andersson's extensive account, another informant, the farmer Carl Andersson from Småland (around 80 years old) sent a response that included no more than eleven handwritten lines. He could not remember anyone at all having talked about anything resembling holidays. As a farmer he had never had leisure time, as it was not possible for him to leave the animals on Friday night and return on Monday morning. Everyone talks about saving money as times are difficult, he added, but when they talk about holidays, they do not seem to miss any money at all (Nm 203, KU 7144). According to the few lines, holidays were 
completely irrelevant to him. With a bit of envy, he snapped at those who actually had some leisure time.

On the pre-printed cover of Carl Andersson's file, the museum curator has noted "Negative response" and under the heading "Fee" there is nothing but a line (whereas the fee for Lisa Andersson was SEK 80). ${ }^{7}$ Remarks like this have not been transferred to the typed questionnaire responses, and the curator's valuation is invisible in the digitised material. In my opinion, this underlines the reason (among others) why researchers should comply with the request on the covers of the typewritten questionnaires: that in the event of publication, it is necessary to compare with the original document.

My very first reaction was that the questionnaire responses would be useless for this study as the dominating group of farmers did not have any leisure time at all. But even though the selected references above relate to the concept of holidays, I presume that the nine storage boxes containing the Semestern responses would give some individual stories about holidays and outdoor activities in the 1930s. And it could probably be productive to complete the study with full text searching in the digitised questionnaire material. But in both cases, it would maybe be like looking for a needle in a haystack, as the material is of such large dimensions and as the questionnaires are created in a foreign context. In addition, if the general purpose is to study the materiality of individual responses, sometimes with photos or drawings, the original documents are essential. Consequently, it is fruitful to approach both the digitised transcriptions and the original documents (cf. Dahlgren 2009).

\section{The Ideas of the Leisure Time Reports}

As mentioned above, my first impression was that the questionnaire material was almost useless when it came to analysing modern 1930s thoughts about holidays and recreation. The retired farmers had never had leisure time at all as they could not leave the animals even for a few days, and certainly not any paid holidays, as the Annual Leave Act did not include them. In contrast, the young people, as seen in Gunnar Lundh's outdoor scenes, seem free and relaxed when they enjoy nature, sunshine and fresh air. I argue that the Government Official Report on leisure time, Fritidsutredningen (SOU 1940:12), acts as a connection between the farmers and the outdoor people. The Annual Leave Act report (SOU 1937:49) was published a few years before the leisure time report, but both projects were carried out during the same period, and they contain cross-references. Both were about the opportunity for the landless population to enjoy nature tourism and outdoor activities; both were intended to promote outdoor life.

The main issue for Fritidsutredningen was to investigate the establishment of recreation reserves for the residents of heavily populated communities (SOU 1940:12). The report clarifies that the whole idea of holidays and outdoor life 
emerged from the welfare project's desire to draw the landless population out into the fresh air. It was primarily workers, often immigrants from rural areas, who more or less voluntarily ended up at the enclosed urban workplaces. A parliamentary bill emphasised that everyone should agree that outdoor life in the woods and fields was the best counterweight to the stresses of the hard-working life (SOU 1940:12: 16). According to the Medicinal Agency, the general pursuit of being in the open air should be facilitated by all available means (SOU 1940:12: 27). All respondents agreed that outdoor recreation was wholesome and necessary for the landless population who sat still at their workplaces all day. A significant part of the report dealt with the question of which fields and areas would be used for the promotion of outdoor life. It was about rules for using certain land areas and even about opportunities for expropriating land in favour of outdoor life, if the land was essential for the general public or for the population in a specific place.

But at the same time as outdoor activities became a popular movement, in line with the ideals of the time, the widespread outdoor activities brought great difficulties, worth evaluating and discussing in the context of the 289 pages of Fritidsutredningen. The problematic background was that between 20,000 and 30,000 Stockholm inhabitants went out in the woods every Sunday. Thus, the urban population's access to the surrounding landscape was a delicate question. It was pointed out that the agricultural and forestry population should, as far as possible, be spared from disturbances by the public on weekends, which could be caused by inconsiderate hikers (SOU 1940:12: 14-18). The main problem was that outdoor activities had become a mass movement that destroyed the ground, because so many people were walking in the woods and the fields. It was a problem that some destroyed and littered while others invaded private property and grounds. This caused conflict with the landowners, such as farmers living near the cities.

The purpose of Fritidsutredningen was to facilitate and look for opportunities for the landless population to engage in outdoor activities, while taking into account the interests of both the farmers and the rural population (SOU 1940:12: 22). Here it is interesting to recall the story about Hugo Stelin and his groups of 500 people that would visit the forest all at once. In this purpose, there is a clear connection between the farmers as landowners, other informants in the questionnaire responses, and the outdoor people depicted in Gunnar Lundh's photographs.

\section{Visual Traces of Modernity}

In autumn 1937, Gunnar Lundh moved to Döbelnsgatan in Stockholm near the swimming facility Vanadisbadet that was under construction at the time. Vanadisbadet is well documented in several of Lundh's photo series, both in colour and black-and-white. Before the official opening in May 1938, he documented 
how the super-modern swimming pool was filled with water, and on the opening day of 15 May, he was there with his camera among the more than one thousand guests. Being the first heated outdoor swimming pool in Stockholm, Vanadisbadet was a unique attraction at a time when Stockholm municipality planned to build swimming facilities in every district-indoors or outdoors, swimming pool or beach -in line with 1930s hygienic and social ambitions. Behind the proposal was Councillor Oscar Larsson, who opened Vanadisbadet in its new, extremely modern building, announcing his motto "Go swimming!" (Svenska Dagbladet, 16 May 1938).
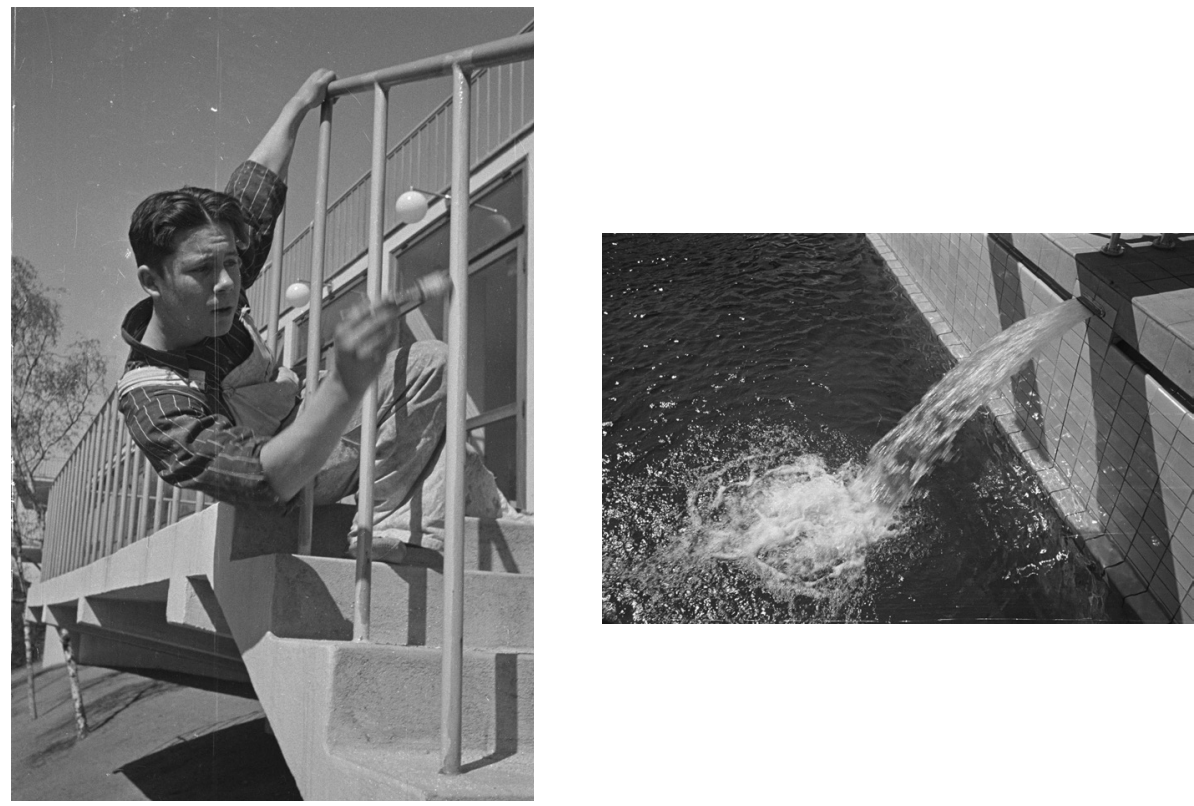

Fig. 16-17 Painting of the banisters outside the entrance to Vanadisbadet; the swimming pool fills with water before the opening day on 15 May 1938. Photo: Gunnar Lundh (GL.128802, GL.128808).

It is interesting to look at Vanadisbadet as it shows how the Annual Leave Act and the leisure time report were implemented in a local, urban political context. Built in high-fashion Swedish "funkis" style, Vanadisbadet provides an insight into the society's view of the importance of health and outdoor life. The unique heated swimming pool was the culmination of the municipality's ambitions to establish bathing facilities in each district. Acting as a news reporter, Gunnar Lundh documented the opening of Vanadisbadet, while as a documentary photographer, he took lots of photos during his obviously frequent visits to the nearby swimming pool. ${ }^{8}$ 

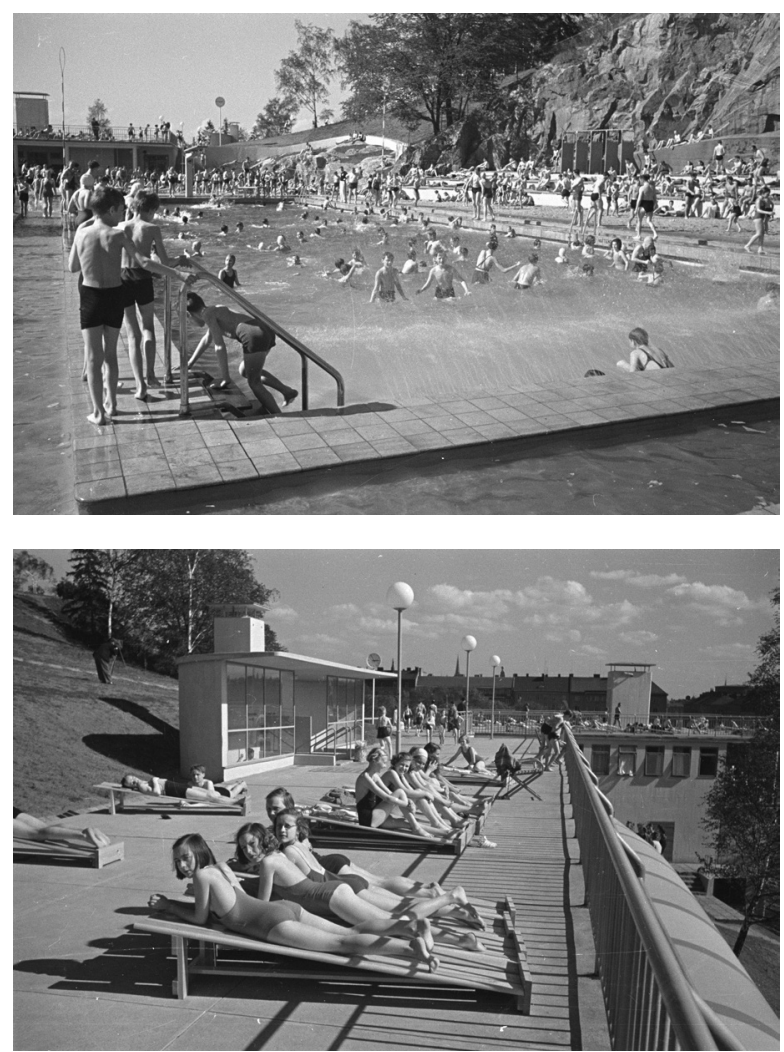

Fig. 18-19 Vanadisbadet, with children playing in the water streams at the end of the pool. Behind the pool; part of the modern funkis building with a café inside and an area for sunbathing on the roof. Vanadisbadet, Stockholm, 17 May 1938. Photos: Gunnar Lundh (GL.129072, GL.129085).

In this article, the digitised archive of the daily newspaper Svenska Dagbladet has been a fruitful way to acquire knowledge about the construction and opening of Vanadisbadet. Again, a bricolage of sources completes the discourse about health and outdoor life in the 1930s. But we still do not know anything about the people depicted. Maybe Lundh was more interested in the image of the modern society than in the individuals he photographed (cf. Strandroth 2007).

\section{Conclusions}

The combination of sources used in this article supports that in the 1930s health project, holidays and outdoor life were part of urban people's lives, while for rural people this was not easily combined with the conditions of agriculture. These results are reflected in the museum's source material as well as in the official government reports, earlier studies and historical sources. In the study, I have used an imaginative mixture of various kinds of sources, according to a method sometimes referred to as bricolage (cf. Jönsson \& Nilsson 2017). 
As the photographs and the questionnaire responses are collections of huge dimensions, they contain a wealth of information, which means that research takes time. In different ways, both express representations of people's everyday lives, even though the people depicted in the photos and their socioeconomic backgrounds are unknown. On the topic of this study, there is a problem that the group of informants consisted predominately of rural people while the impression of the photos is that they mainly depict urban people's interests and habits. Even though there is a gap between the photos and the informants' responses, another, deeper study could possibly help broaden the image of outdoor activities in people's everyday lives in the 1930s. The bricolage method points out that the combination of sources broadens the image of different groups' relationships to outdoor life.

I have described my browsing through the hundreds of contact sheets as looking at a film, but without the names of the actors. Even though the knowledge of the mycologist Hugo Stelin makes the film more interesting, it is my opinion that the series of photos visualise events that broaden the image of 1930s outdoor life. A single photo can be the basis for different interpretations; it can tell us much or it can be quite anonymous. The contact sheets, with their series of photos, have been essential insofar that they have added knowledge beyond the individual photos. While studying the photos and the questionnaire responses, it is enriching to explore both the functional archive context, the physical materiality of the documents and the content of the stories expressed by photos and informants, including relevant evaluation of the sources.

The digitising of the photographs and the questionnaire responses has made the collections searchable and available in a positive way. However, the fact that the responses to "my" questionnaires had been omitted made me think of how the result is affected by whether the material is digitised or not. Reading the original documents is rather different from searching for keywords in the database. It is constructive to look at the original documents as well as searching in the database, when possible. Digitisation opens new search options on various themes, but the accessibility depends entirely on which material is entered into the database and how it is documented and tagged. Within the VBB project, we have realised that the work of entering new information into the database is extremely time consuming.

Marianne Larsson holds a PhD in ethnology from Stockholm University. She is currently a curator at The Nordic Museum in Stockholm. Her main research area is related to outdoor life and casual clothing. Her doctoral thesis is about Post Office uniforms and the interaction between texts, images and objects. She participates in the research project Images and Stories of Everyday Life. E-mail: marianne.larsson@nordiskamuseet.se 


\section{Notes}

1 Today Svensk Form/Swedish Design.

2 He likely knew about the ongoing photo documentary FSA project in the USA with its purpose to improve the situation of the poorest farmers in the American countryside (see Strandroth 2007).

3 The name "Siv Smith" is also noted, but she is still unknown.

4 For a view of the mushroom poster (Stelin 1950), see NM.0322229 in the Nordic Museum's collections.

5 For information about the composition of the groups of informants, see Österman 1991: 64-75. The author confirms that the group was dominated by farmers, although many other professions were represented.

6 The introduction of the Swedish Tourist Association's youth hostels is described in Eskilsson 2008.

7 Österman points out that only modest fees were rewarded (1991: 13).

8 Gunnar Lundh also documented other modern swimming facilities in and around Stockholm.

\section{References}

\section{Unprinted sources}

\section{The Nordic Museum}

Aftonbladets svampkarta (Stelin 1950), NM.0322229. https://digitaltmuseum.se/ owners/S-NM.

Gunnar Lundh's archive (1961/063).

Nylén, Anna-Maja (1961). "Traditionsuppteckningar och nutid", Meddelanden från Etnologiska undersökningen, 86.

Nylén, Anna-Maja (1964). ’Om 'man' och strukturförändringen”, Meddelanden från Etnologiska undersökningen, 89.

Questionnaire responses

Nm 72, Kalendern och dess märkesdagar (1943).

Nm 159, Bad (1952).

Nm 198, Fritiden 1973 (1973).

Nm 203, Semestern (1978)

Sp 70, Midsommar (1939).

Sp 212, Cykeln (1966).

\section{Others}

Svenska Dagbladets historiska arkiv: https://www.svd.se/arkiv

SAOB, 1935: Kamping, https://svenska.se/saob/?id=K 0233-0113.ZYNm\&pz=7, taken 2018-08-16. 


\section{Culture Unbound}

Journal of Current Cultural Research

\section{Literature}

Dahlgren, Anna (2009): "Tankar om tillgänglighet och fotografier i arkiv", Anna Dahlgren \& Pelle Snickars (eds): I bildarkivet: Om fotografi och digitaliseringens effekter, Stockholm: Kungliga biblioteket, 59-89.

Ekström, Gert (2001): Älskade cykel: År 1800-2000, Stockholm: Prisma.

Eskilsson, Lena (1995): "Fritiden: om fritidens idé och en utställning i Ystad 1936", Tvärsnitt: Humanistisk och samhällsvetenskaplig forskning, Stockholm: Humanistisk-samhällsvetenskapliga forskningsrådet (HSFR), 1995:4, 16-29.

Eskilsson, Lena (2008): "Friluftsliv", Jakob Christensson (ed.): Signums svenska kulturhistoria: Det moderna genombrottet, Stockholm: Signum, 362-391.

Franklin, Stuart (2016): Documentary Impulse, Phaidon Press Ltd.

Frykman, Jonas (1992): "In Motion: Body and Modernity in Sweden between the World Wars", Ethnologia Scandinavica, 36-51.

Hirdman, Yvonne, Jenny Björkman \& Urban Lundberg (2012): Sveriges historia 1920-1965, Stockholm: Norstedt.

Jönsson, Lars-Eric \& Fredrik Nilsson (eds) (2017): Kulturhistoria: En etnologisk metodbok, Lund: Lunds universitet.

Larsson, Marianne (2011): Män i baddräkt: En kroppslig kulturhistoria, Stockholm: Nordiska museet.

Larsson, Marianne (2014): "Class and Gender in a Museum Collection: Female Skiwear", Marie Riegels Melchior \& Birgitta Svensson (eds): Fashion and Museums: Theory and Practice, London/New York: Bloomsbury, 91-107.

Lyngø, Inger Johanne (ed.) (1993): På vandring: En tur i friluftslivets historie, Den Norske Turistforening 125 år (exhibition catalogue). Oslo: Norsk Folkemuseum.

Modern Leisure: A Swedish Exhibition, June 19-Aug. 23, 1936(1936), Ystad exhibition in cooperation with The Swedish Traffic Association (exhibition catalogue).

Nilsson, Bo G., Dan Waldetoft \& Christina Westergren (eds) (2003): Frågelist och berättarglädje: Om frågelistor som forskningsmetod och folklig genre, Stockholm: Nordiska museet.

Pihl Atmer, Ann Katrin (1998): Livet som leves där måste smaka vildmark: Sportstugor och friluftsliv 1900-1945. Stockholm: Stockholmia

Ranby, Caroline (2013): Kongl. hoffotograf Peter P. Lundh: Det bästa ljus och nutidens bästa instrumenter. Höganäs: Höganäs museum \& Höganäs bokhandel \& förlag.

Sandell, Klas \& Sverker Sörlin (eds) (2008): Friluftshistoria: Från "härdande friluftslif" till ekoturism och miljöpedagogik: teman i det svenska friluftslivets historia, Stockholm: Carlsson.

Svanberg, Ingvar \& Hanna Lindh (2019): "Mushroom hunting and consumption in twenty-first century post-industrial Sweden", Journal of Ethnobiology and Ethnomedicine, 15:42, 1-23.

SOU 1937:49: 1936 års semestersakkunniga: Betänkande med förslag till lag om semester.

SOU 1940:12: Fritidsutredningen: Betänkande med utredning och förslag angående inrättande av fritidsreservat för städernas och de tättbebyggda samhällenas befolkning.

Stelin, Hugo (1936): Aftonbladets och Nordiska kompaniets svampbok, Stockholm: Nordiska kompaniet.

Stelin, Hugo (1950): Aftonbladets svampkarta - svampbok, Stockholm: Aftonbladet.

Strandroth, Cecilia (2007): In Search of the Pure Photograph: A Historiographic Study of the Farm Security Administration, Walker Evans, and the Survey Histories of Photography, doctoral dissertation, Uppsala university.

Strid, Åke (1999): "Hugo Stelin-en av stockholmsmykologerna: 2. Utåtriktad verksamhet och samarbetet med Aftonbladet.", Jordstjärnan: medlemsskrift för Sveriges Mykologiska förening, 20:1, 20-36. 
Svenska Dagbladets Årsbok 1936, Stockholm: Svenska Dagbladet, 76-77.

Söderberg, Rolf \& Pär Rittsel (1983): Den svenska fotografins historia: 1840-1940, Stockholm: Bonnier fakta.

Österman, Annika (1967): "När cykeln kom till byn”, Nordiska museets och Skansens årsbok 1967, 166-170.

Österman, Annika (1991): Människors egen historia: Om Nordiska museets frågelistverksamhet, Stockholm: Nordiska museet. 